Georgia State University

ScholarWorks @ Georgia State University

6-2-2011

\title{
Was the Great Depression the Fault of Government and Unions? An Institutional/Keynesian Analysis
}

Bruce E. Kaufman

Georgia State University, bkaufman@gsu.edu

Follow this and additional works at: https://scholarworks.gsu.edu/uwrg_workingpapers

\section{Recommended Citation}

Kaufman, Bruce E., "Was the Great Depression the Fault of Government and Unions? An Institutional/ Keynesian Analysis" (2011). UWRG Working Papers. 33.

https://scholarworks.gsu.edu/uwrg_workingpapers/33

This Article is brought to you for free and open access by the Usery Workplace Research Group at ScholarWorks @ Georgia State University. It has been accepted for inclusion in UWRG Working Papers by an authorized administrator of ScholarWorks @ Georgia State University. For more information, please contact scholarworks@gsu.edu. 
Working Paper 2011-6-2

June 2011

\title{
Was the Great Depression the Fault of Government and Unions? An Institutional/Keynesian Analysis
}

\author{
Bruce E. Kaufman \\ Georgia State University
}


Was the Great Depression the Fault of Government and Unions?

An Institutional/Keynesian Analysis

\author{
Bruce E. Kaufman \\ Department of Economics, Andrew Young School \\ Georgia State University \\ Atlanta, GA 30303 \\ bkaufman@gsu.edu
}

June 15, 2011 
Was the Great Depression the Fault of Government and Unions?

An Institutiona1/Keynesian Analysis

Abstract: A growing number of economists blame the length and severity of the Great Depression on factors that rigidified wage rates, raised production costs, and interfered with flexible allocation of labor. The centerpiece of this critique is President Roosevelt's New Deal labor program, portrayed as creating a series of large negative supply shocks through encouragement of unions, minimum wages, unemployment insurance, and other anti-competitive industrial relations practices. This paper presents the other side of the story using a combination of institutional and Keynesian theory, drawn principally from the work of J.R Commons and J.M. Keynes. Both "spending" and "industrial relations" rationales for stable wages are developed; also developed is the positive economic case for the New Deal labor program. Attention is called to the long-neglected macroeconomic dimension of industrial relations.

The plunge of the world economy into crisis in 2007-2010 brought with it renewed research and debate on the cause and longevity of the Great Depression of the 1930s. Economic opinion on this matter varies along a wide spectrum; nonetheless, the drift in the literature is toward a view that argues the depression was greatly exacerbated by factors that rigidified wage rates, increased labor costs, and interfered with flexible demand/supply (DS) allocation and use of labor resources. The government is highlighted for blame, particularly with regard to the New Deal's legislative program fostering greater unionization, a legal minimum wage and unemployment insurance, but also criticized are labor unions and the anti-competitive industrial relations (IR) practices adopted by large corporations. This line of thought provides powerful ammunition for economists who argue that government policy during the 2007-2010 economic crisis represents a dismaying repeat of the mistakes of the 1930s. That is, the 2007-2009 threestep increase in the minimum wage, the higher costs on business from the 2010 health care legislation, and the prospect of greater unionism should Congress enact the Employee Free Choice Act (card check recognition), are portrayed as cost-raising negative shocks that reduce employment and help tip a weak economy into a deeper slump (Neumark 2009; Galloway 2010). 
This paper provides a contrasting point of view built on a combination of institutional and Keynesian economic principles, particularly as contained in the writings of J.R. Commons and J.M. Keynes. The body of the paper is devoted to: (1) theoretical explanation of Commons' and Keynes' complementary rejection of the orthodox "invisible hand" model of a flexible price selfadjusting economy; (2) explication of an alternative but little-known four-pronged institutional theory of wages developed during the 1920s; (3) application of the institutional/Keynesian theories of macroeconomics and wages to the cause and severity of the Great Depression; and (4) explanation of why Roosevelt, Commons and Keynes all favored a labor reform program of minimum wages/maximum hours, expanded collective bargaining, and new social insurance programs (social security, unemployment insurance) as one of the New Deal's primary instruments for promoting economic recovery. The conclusion is that blaming government, unions, and IR practices for the debacle of the 1930s is greatly misdirected. The paper does not consider the most recent economic crisis; however, a parallel interpretation is certainly apropos.

\section{Contemporary Economists on the Great Depression}

Current Federal Reserve Bank (“Fed”) chair Ben Bernanke (2000: 5) quipped that understanding the Great Depression is the "Holy Grail of macroeconomics." Although the Grail has not been precisely located yet, many economists believe they have gotten much closer. Parker (2007), for example, narrows the contending explanations to three: the "Monetary Hypothesis," the "Nonmonetary-Financial Hypothesis," and the "Gold Standard Hypothesis," with the Monetary Hypothesis occupying the dominant but not exclusive position. Depression aficionados among economists are still actively debating the relative role of each; among mainstream economists, 
however, the tendency is to synthesize them into one more or less consistent "Grail" story. As an

example, Calomiris (2007) gives this relatively short and succinct consensus summary:

The Depression resulted primarily from poor monetary policy by central banks, including the Federal Reserve, and was perpetuated by a combination of disastrous fixed-exchangerate policies (which transmitted deflation around the world), protectionism, and the severe problems with the balance sheets of banks and firms. In the United States, added damage was done by the wrong-headed policy responses of the Hoover and Roosevelt administrations, including New Deal policies that raised prices and wages.... Whatever the desirability of the New Deal policies from other perspectives, they did not provide an effective boost to the economy (p. 143).

The role of labor markets, industrial relations practices, and New Deal labor policies, earlier a distinctly secondary-to-peripheral issue (e.g., Romer 1993), has recently become a particular focus of attention and criticism. The reason for the attention is explained by Nobel laureate Edward Prescott (1999): "The Great Depression and business cycles are similar in that both include variation in output accounted for in large part by variations in labor input to production" (p. 26, emphasis added). Thus, Prescott is saying that "most of the action" in explaining the slump, at least in terms of real GDP, is in the labor market. In particular, he shows that the largest source of GDP decline was due to a large decline in average hours worked -interpretable as a large negative productivity shock coming from rigid wages (hence much higher unemployment and lost work hours), new industrial relations practices (e.g., industrial unionism with many strikes), and cost-raising New Deal labor policies. Prescott states, therefore, "I am led to the view...that there must have been a fundamental change in labor market institutions and industrial policies that lowered steady-state, or normal, market hours" (p. 26).

Other economists, particularly working out of a New Classical and Real Business Cycle framework, have reached similar conclusions. In "Accounting for the Great Depression," Chari, Kehoe and McGrattan (2003) point the finger of blame at frictions in labor and capital markets 
that introduce distortionary wedges in the price system. Their empirical analysis indicates the most important cause of the downturn and slow recovery was the labor wedge, leading them to conclude "These poor [labor] policies turn what otherwise would be modest downturns into prolonged depressions" (p. 3). Similarly, Madsen (2004) concludes, “There is a general consensus among economists that adverse nominal demand shocks had severe and long-lasting employment and output effects during the Great Depression because rigid labor markets prevented wages from adjusting to the declining price level” (p. 263).

Another influential voice is Lee Ohanian who asks in the title of a recent article (Ohanian 2009), “What - or Who - Started the Great Depression?” He answers “Herbert Hoover” (p. 2310) and then later labels Hoover a "New Dealer." Blaming Hoover is perhaps surprising, given the popular impression that Hoover (a conservative Republican president) followed a mostly orthodox "do-nothing" and "let the market work" policy as the depression deepened. But as Ohanian correctly points out, Hoover in certain respects followed an interventionist course; most particularly, starting quickly in the fall of 1929 and continuing thenceforth he vigorously lobbied employers to maintain wage rates and avoid wage cuts. Hence, as prices dropped real wages increased above the (presumptive) equilibrium level in labor markets, leading to growing job loss and unemployment. According to Ohanian, firms in the early 1930s wanted to cut wage rates but reluctantly refrained because Hoover offered them a quid pro quo - he would keep unions at bay if they kept wages up. Thus, Ohanian concludes, "the key to understanding the Depression is understanding and quantifying this labor market distortion” (p. 2314).

These views on wages and the Great Depression do not represent those of all mainstream economists (e.g., Rees, 1970; Tobin 1975; Solow 1990; Temin 2007; Stiglitz, 2010) - nor certainly those in more heterodox circles (e.g., Perelman 2007); nonetheless, "fundamentalist" 
ideas on the self-correcting nature of capitalist economies that were three-four decades ago widely regarded as on the right-wing fringe have steadily gained ground and are now supported in broad outline even by people identified as "liberal economists" and "New Keynesians."

\section{Commons and Keynes on Macroeconomics and the Great Depression}

The alternative perspective on the Great Depression and New Deal offered here is a melding of ideas from two founding fathers: J. R. Commons who founded American industrial relations and co-founded institutional economics and J.M. Keynes who founded the Keynesian school of macroeconomics. Brief overview of their ideas provides context for the theory that follows.

Commons and Keynes are not names often linked together, one being a mostly neglected American institutional labor economist and the other a world famous English monetary macroeconomist. ${ }^{2}$ In reality, both not only shared common concerns, interests and viewpoints on economic matters but carried on a correspondence going back to at least 1925 (Skidelsky 1983). Recent archival research by Whalen (2008b) and Kates (2008) reveals that Commons and his student Harlan McCracken were, in fact, an important intellectual source for several of Keynes' basic ideas in the General Theory, particularly his formulation and critique of Say's Law.

Two shared principles brought Commons and Keynes together. The first is their mutual concern over unemployment. Both men state (e.g., Commons 1923a: 167; Keynes 1936: 372)

\footnotetext{
${ }^{1}$ Out of the mainstream circa the 1970s is Rothbard's (1972) statement, "If government wishes to see a depression ended, .... [t]he first and clearest injunction is: don't interfere with the market's adjustment process" (p. 25, emphasis in original). Samuelson (1948), on the other hand, expressed the postwar Keynesian consensus: "the private economy is not unlike a machine without an effective steering wheel or governor" (p. 412). The distance traveled in the last three decades from Keynes toward Rothbard (and Robert Lucas) is revealed in textbooks; Samuelson dropped his statement in later editions and now liberal economists, such as Krugman and Wells (2009), tell students: "The economy is self-correcting in the long run" (pp. 339-41, repeated four times).

${ }^{2}$ A small literature on Commons and Keynes exists: see Chasse (1991), Atkinson and Oleson (1998), Tymoigne (2003), Kates (2008), and Whalen (2008a, 2008b). No one covers the IR dimension done here. Rutherford and Desroches (2008) describe the diverse and to some degree divergent institutionalist thought on Keynes in the 1930s.
} 
that large-scale, persistent unemployment is capitalism's greatest cause of inefficiency and human suffering and they made finding solutions to unemployment both a scholarly and political mission. The second is belief that competition and flexible prices do not provide an effective self-regulating mechanism and therefore the economy may suffer extended slack with no tendency to full employment. For this reason, both Commons and Keynes rooted their macroeconomic theories in the heterodox line coming from Malthus (attacking Say's Law) rather than the orthodox line coming from Ricardo (Commons 1934: 846; Keynes 1936: 32).

Say's Law holds that a competitive market economy with flexible prices cannot experience a prolonged excess supply condition in product and labor markets. (Kates 1998). The corollary implication is that a market economy has a built-in tendency to return to full employment equilibrium. Commons and Keynes took an historical and evolutionary view of capitalism; in particular, they believed that the institutional structure of economies evolves through distinct stages of development (Crotty 1990; Atkinson and Oleson 1998). ${ }^{3}$ Commons (1934) maintained, for example, that the mid $-19^{\text {th }}$ century American economy was sufficiently atomistic and competitive that it operated as DS theory predicts. However, by the 1920s the economy had transitioned to "managerial capitalism" with a dualistic-type economy having a competitive periphery and oligopolistic industrial core. The industrial core, in turn, featured giant corporations, mass production, large fixed capital investments, and well developed internal labor markets (ILMs). The result is that DS and flexible prices/wages are substantially displaced by the

\footnotetext{
${ }^{3}$ For example, the aggregate labor supply curve was probably forward-sloped in the pre-Civil War economy because workers had good substitutes for wage-type jobs when demand shocks forced down wage rates (e.g., a move to selfemployment in farming or gold mining). In an industrial economy, urban wage employees have few if any substitute sources of labor income and, hence, in the region of subsistence income the labor supply curve becomes increasingly elastic and negatively sloped as workers and family members work whatever hours are required for survival (Sharif 2000; Dessing 2002). One purpose of a modern welfare state (e.g., unemployment insurance), as advocated by Commons and Keynes, is to put a floor under family income and thus stabilize the labor market and economy. New Classical macroeconomists, on the other hand, explain the high unemployment of the depression as a voluntary inter-temporal substitution of leisure for work in response to lower wages (e.g., Lucas and Rapping 1969).
} 
coordinating forces of management and administration. Thus, Commons (1923c: 116-17) states, "There is no invisible hand about it, no natural equilibrium of forces of nature that augments the national wealth by mere unguided self-interest." Since a modern economy lacks an effective selfregulating mechanism, Commons (1934; also Whalen 1993, 2008b) maintained government must steer it with a "Visible Hand" to stabilize aggregate demand and achieve a "managed equilibrium." If government, on the other hand, stands on the sidelines and lets DS work unimpeded, the result will be grave inefficiency and an implosion in times of crisis.

Institutionalist Gardner Means (Lee and Samuels 1992) greatly developed some of these ideas in the 1930s. He argued that administered pricing in the industrial core shifts most of downward price and wage adjustment to the competitive segment (e.g., agriculture, coal mining, textiles) where workers and firms - not economically well-off to begin with -- feel the brunt of deflation.

Keynes also rejected Say's Law and maintained that the aggregate labor market is not self-correcting through flexible wage/price movements (Tobin 1975; Davidson 2007; Levendis 2007). ${ }^{4}$ The conventional interpretation of Keynes, as found in most textbooks and New Keynesian and New Classical macroeconomics (see Riggi 2010), is that he argues markets do not clear on account of inflexible prices and wages, due in part to workers' money illusion. ${ }^{5}$ A reading of Chapters 2, 19, and 23 of the General Theory reveals this is not at all Keynes' position. In Ch. 2 he acknowledges money wages have a large degree of downward

\footnotetext{
${ }^{4}$ Keynes made a second fundamental revision to orthodox theory. In the neoclassical model the real wage determines the level of employment via the aggregate labor demand (marginal product) curve, hence higher wages cause unemployment; Keynes and post-Keynesians argue that employment is determined in the goods market by effective demand and this then determines the real wage via the marginal product schedule (not itself a demand curve). A higher real wage can increase employment, therefore, if it sufficiently increases spending. Other features (e.g., a minimum staffing level) make the wage/employment function upward sloping (Lavoie 1992).

${ }^{5}$ Hansen (1923) suggests that what looks like workers' irrational money illusion is actually rational behavior in response to weak bargaining power. He explains: "The wage-earner is more concerned with the price of his commodity than with the total volume of his sales....The loss of employment he conceives of as temporary; the loss of his established wage he believes is a permanent loss" (p. 40). For example, at International Harvester wages were cut in 1921-22 and never recovered their 1920 level for the rest of the decade (Ozanne 1968).
} 
rigidity but asserts (p. 10) that even if money and real wages are perfectly flexible the labor market may not clear and thus continue to exhibit persistent involuntary unemployment. ${ }^{6}$ Thus, wage cutting as a cure for unemployment is not only impractical but also fallacious (Tobin 1975; Levendis 2007). One reason given is that the firm's hiring decision is made on the basis of the real wage but workers can only agree to a cut in the money wage - a cut that will likely precipitate a fall in prices and thus leave the real wage the same or even higher, as happened in the early 1930s (Mitchell 1986, 1993). A second reason is that at the aggregate level a cut in money and real wages affects firms' labor demand in offsetting directions; that is, a lower wage reduces the cost of production and increases employment as firms move down the aggregate labor demand curve but it also reduces household income and spending and therefore leads to a contraction of employment as the curve shifts leftward. Then, in Chapter 19 he considers the role of wage flexibility in more detail and concludes, "To suppose that a flexible wage policy is a right and proper adjunct of a system which on the whole is one of laissez-faire, is the opposite of the truth" (p. 269, emphasis in original) and therefore "the maintenance of a stable general level of wages is, on a balance of considerations, the most advisable policy" (p. 270). In Chapter 23 Keynes acknowledges that this position puts him amongst the "brave army of heretics." (p. 371).

Commons came to exactly the same conclusion as Keynes on the desirability of a stable wage/price policy. Wage/price stabilization, according to Commons (1923a, 1925), is made necessary because of several factors, including: (1) large wages and price changes amplify (rather than dampen) business cycles, (2) the large fixed costs of modern industry create pressures for large and cascading price/wage declines in periods of recession, and (3) workers demand higher wage rates and other forms of protection to offset wage/employment variability.

\footnotetext{
${ }^{6}$ This more "fundamentalist" interpretation of Keynes is supported by Samuelson (1946) who states, "Keynes denies that there is an Invisible Hand.... This is the sum and substance of his heresy" (p. 321, emphasis in original).
} 
Keynes argued that the fundamental defect of wage deflation is that it leads to reduced production and employment (i.e., income effects dominate substitution effects) - the opposite of what a self-adjusting economic system is supposed to do. ${ }^{7} \mathrm{He}$ primarily focused on the negative effect of wage cuts on spending and aggregate demand. Commons accepted the spending argument; being a labor economist, however, he emphasized far more than Keynes a second fundamental channel through which wage deflation hurts the economy, This is the negative impact wage cuts, and market volatility in general, have on productivity and aggregate supply.

The Walrasian theory underlying Say's Law models labor as a commodity and the production function as a purely technological relationship; hence, wage/price variability and management treatment do not affect the amount of output yielded per unit of labor input (Kaufman 2010a). Commons (1919, 1921a, 1921b, 1923c, 1934) claimed otherwise for six reasons. First, because labor is human the amount of labor services provided depends on psychological factors that influence work motivation, such as morale, fairness, and expected gain. Ups and downs in employment and wages undercut work motivation by destroying morale, fostering perceptions of unfairness and inequity, and undercutting the prospect of long-term gain from hard work and cooperation. Second, labor market volatility also undercuts the incentive of firms and workers to invest in human capital since the returns are reduced and made more uncertain by more frequent job interruptions and shifts. Third, workers react to market volatility by seeking a variety of protective/defensive stratagems that are harmful to productivity, such as stretching out the work, work rule restrictions, and trade unions. ${ }^{8}$ Fourth, unstable markets

\footnotetext{
${ }^{7}$ Keynes accepts that wage reductions at the firm/industry level may have a positive employment effect; this may also be true at the aggregate level when exports are a large share of GDP (but unlike the USA in the 1930s).

${ }^{8}$ In this vein, a business writer (Tipper 1922: 879) states, "The working of this law of supply and demand for 400 years in the industrial system has increased the number of adherents to workers' organizations from a few hundred to some thirty million in various countries, so that it is not likely that the workings of this law will reduce either the number or the strength of such organizations." It is then instructive to observe that in 1933 the first industries to massively organize under the New Deal were coal and textiles/apparel - both highly competitive (Vittoz 1987).
} 
undercut the willingness of firms to invest in high road employment systems and high

performance work practices since these require considerable fixed investment cost with

relatively long-term returns. A fifth is that unemployment and insecurity reduce the quality of the

nation's labor input, such as by eroding people's work ethic and personal character, and create

costly social pathologies (e.g., alcoholism, homelessness). And, finally, a sixth and overarching

problem is that high performance production is promoted by a cooperative/unitarist employment

relationship where both managers and employees work together to promote the long-term

success of the company -- an ethos that a short-term and uncertain market-mediated relationship

quickly turns into an adversarial employment relation with attendant low trust, low productivity,

high conflict, and opportunistic rent-seeking behavior (Moriguchi 2005). ${ }^{9}$ From Commons'

perspective, therefore, the employment relationship is a classic form of Prisoner's Dilemma

game and unrestricted DS causes employers and employees to gravitate to a win-lose or even

lose-lose outcome; the purpose of industrial relations, in turn, is to use science, practice and

policy to help employers and employees escape this trap and reap a mutual gain outcome (Miller

1991; Kaufman 2010a). ${ }^{10}$

\section{Industrial Relations Theory and Practice in the New Era}

\footnotetext{
${ }^{9}$ Commons (1934:5) makes property rights the foundation of institutional economics; looked at this way, the fundamental defect of a DS employment relationship is that the worker has no stable property right in a job and hence no reason to do more than the short-term minimum to keep it. As Slichter (1928) notes, however, "Stabilized employment.... transforms the entire attitude of the wage-earner toward his job. The job .... becomes a highly valued piece of property.... This fact that he now has something worth keeping produces radical changes in his willingness to be efficient" (p. 185). This locates the fundamental weak spot in orthodox labor theory; that is, its efficiency properties depend on complete contracts and perfectly defined property rights but labor has neither. ${ }^{10}$ Shidle (1920) explains how to use IR principles to avoid the prisoner's dilemma: "[T] opportunity to play more than fair with their workmen, when the situation is such that they might 'get away with things'.... will later find themselves well equipped with the loyalty and enthusiasm of their entire force if the pendulum swings back again" (p. 370). Similarly, Basset (1922) states, "We get nowhere at all when we conceive industry as 'low wages and high profits,' or as 'high wages and low profits.' The 'low' and 'high' do not go together [for cooperation].... For the employer who grinds down the workers rarely gets any profits, and the group of workers who grind down the employers only grind down the industry that gives them employment" (p. 11).
} 
Both Keynes and Commons concluded that the advanced industrial countries of the 1920s had entered into an era requiring stabilization of markets. Commons came to this conclusion earlier, however, and his opinion was more widely shared in the USA than was the case for Keynes in the UK. This fact reflects in part the much greater diversity in economic opinion and schools of thought in America relative to the UK during the interwar period (Morgan and Rutherford 1998); it also reflects the much greater transformation experienced by America in the 1920s with regard to modern mass production methods and new IR systems. It is the latter I focus on because it provides an important link to the institutional/IR explanation for the Great Depression and the rationale for the high wage labor policies of both Hoover and Roosevelt treated later in the paper.

America experienced a decade of industrial growth and employment relations transformation in the 1920 s so profound and path-breaking that delegations of visitors from around the world came to see it firsthand (Kaufman 2004). Labor economist Paul Douglas (1928) remarked, "We are at present overrun with a large number of foreign visitors who are seeking the secret of our prosperity" (p. 28). The name most associated with this transformation was Henry Ford; a second oft-mentioned name was Frederick Taylor.

In the early 1910s Henry Ford was a relatively unknown owner of a small-sized auto assembly plant in Detroit. His factory used the traditional decentralized "hire and fire" and "foreman in control" employment system then prevalent (Jacoby 1985; Kaufman 2008, 2010b). In 1913, however, Ford caught national attention when he introduced the first integrated, largescale assembly line form of production. The production time for a new car fell from twelve and one-half hours to one and one-half.

Although the assembly line allowed Ford to dramatically lower prices and yet make more profit on much expanded volume, he soon discovered another part of his operations that needed 
major innovation and restructuring. This was his employment system (Meyer 1981; Kaufman 2010b). The assembly line production method was highly efficient but depended on continuous operation, seamless integration of tasks, and workers with considerable endurance and tolerance for fast-paced and highly specialized/monotonous jobs. Interruption at any point threatened to bring the entire factory to a stand-still with red ink soon gushing from the burden of large fixed costs. This was exactly the situation Ford confronted because of labor problems. Turnover at Ford's mushroomed to 370 percent on an annual basis; likewise, absenteeism on Mondays was typically over 10 percent and foremen had to scramble to hire hundreds of temporary workers.

Ford's solution to his labor problem was to completely revamp the employment system. The most famous action was to nearly double the rate of pay to a minimum of $\$ 5.00$ a day (from around \$2.50) - a move that earned him international celebrity status. But Ford did far more than simply raise wages. He also created an integrated and highly formalized human resource management function with a centralized employment department, job/wage classification system, training program, extensive welfare (benefit) programs, replacement of employment-atwill with termination-for-cause, and a grievance/mediation committee. A company historian writes, "Thus, the Ford Motor Company, which in 1911 had no labor policy at all, possessed three years later the most advanced labor policy in the world" (Nevins 1954: p. 541).

The industrial relations innovations at Ford spread to many other companies in the 19181929 period. Labor economist W. Jett Lauck (1929) observed in this regard, "There is another great change going on in thousands of places scattered all over the country, namely the acceptance of cooperative management" (p. 75). Considerable diversity existed among companies in terms of breadth and depth of new employment practices but the vanguard popularly called welfare capitalist employers and accounting for between 15-25 percent of 
industrial employment (Commons 1921b) -- constructed a transformed employment system with a formalized personnel department, array of employee benefit programs, training programs, job security and promote-from-within provisions, and employee representation plan (Bernstein 1960; Jacoby 1997; Kaufman 2008). The epicenter of the new industrial relations movement was the ten companies that comprised the Special Conference Committee (SCC). The SCC was a group that met behind the scenes to promote progressive but nonunion IR practices; it was financially supported by John D. Rockefeller Jr. and included major corporations such as General Electric, Goodyear, International Harvester and Standard Oil of New Jersey (Kaufman 2003a).

Both the Commons and Rockefeller wings of early IR advocated a strategy in which companies (and nations) obtain competitive advantage using a transformed employment model emphasizing cooperation, mutual gain, and employee commitment (Kaufman 2003b). Commons (1919) called this the "goodwill" model and he and others (King 1918; Hicks 1941) enumerated specific IR practices that accompany it, such as above-market wages, job security, and participation/voice mechanisms. These new IR practices involved considerable cost, transformed labor from a largely variable to a semi-fixed cost, and by creating formal ILMs greatly reduced the influence of external market forces on terms and conditions of employment. The companies believed, however, that the higher productivity, greater worker loyalty, and reduced conflict and likelihood of unionization they gained more than offset the costs (Jacoby 1997; Moriguchi 2005). Reflective of these new ideas, Edward Cowdrick (1930), secretary of the SCC, observed, “[I]n recent years there has been a distinct trend away from the idea that labor is bought and sold, and toward a conception of employment as a lifetime relationship" (p. 47). ${ }^{11}$ These ideas resurfaced

\footnotetext{
${ }^{11}$ Also illustrative of the change in employment/wage philosophy is practice in the steel industry. The Iron Trade Review (1/5/22: 10) declared in early 1922, "Great progress has been made in liquidating wages in the iron and steel industry. The hourly common labor rate paid by the United States Steel Corporation today is 30 cents, as compared
} 
five-to-six decades later as part of the commitment, high involvement, and high performance human resource paradigm (Walton 1986; Kochan, Katz, and McKersie 1986; Lawler 1992).

\section{Wage Theory in the New Era}

Keynes' Cambridge University colleague Arthur Pigou reiterated the case in his Theory of Unemployment, published in 1933, for the orthodox proposition that unemployment in the labor market is a sign that real wages are too high (i.e., workers have priced themselves out of the market) and a cut in money wages is one way to restore full employment equilibrium. Keynes portrayed Pigou's position as the exemplar statement of orthodox doctrine and juxtaposed his General Theory as a revolutionary denial of it. What Keynes neglected to acknowledge was that a significant portion of American economists and industrial practitioners had abandoned the DS theory of wages and deflationist strategy toward unemployment a decade earlier. ${ }^{12}$

A detailed account of the orthodox and emergent institutional theory of wages, as seen in America from the vantage point of the 1920s, is provided by Lauck in The New Industrial Revolution and Wages (1929). ${ }^{13}$ Lauck states regarding neoclassical DS theory (p. 7), 'Labor's value was generally looked upon and determined in the same way as that of purely physical commodities, such as wheat, coal, iron, textiles, and steel products." He goes on to say (p. 271),

The free play of the forces of supply and demand.... in fixing rates of pay of industrial workers, was formerly looked upon as an expression of the so-called immutable laws of economics which it would be almost sacrilegious to attack. It would be as futile, it was assumed, to play with the forces of supply and demand as it would be to attempt to mitigate the operation of the law of gravity.

\footnotetext{
to.... the peak Feb. 1, 1920 at 50.6 cents.” A decade later James Farrell, president of U.S. Steel, declared, "Wages in the steel industry are not coming down - you can count on that" (Literary Digest, 11/8/30: 11).

12 Davis (1971) documents that many American economists also favored deficit spending in times of depression; Mitchell (1986) describes the diverse and somewhat muddled view held at this time on wages and unemployment.

${ }^{13}$ Modern theories of wage rigidity are reviewed in Groshen and Schweitzer (1997) and Bewley (1999). Lauck was a well-known labor economist and social reformer with academic (e.g., Chicago) and union ties (Grayson 1975).
} 
Lauck then describes the transformation in wage theory in the 1920s. He states (p. 271), "Within a few short years, however, this more-than-a-century-old theory has been cast aside. It has been recognized that the human element in production [the critical idea in institutional/IR theory ] should not be purchased on the same basis as raw materials or capital equipment." ${ }^{14}$ This new view, in turn, came from recognition of the need to stabilize spending (Keynes) and the need to stabilize industry (Commons). On the former he states (p. 2):

It was the effort to revive the prostrated industry and trade of the country [from the depression of 1920-1922] that finally led to the new economic regime through which the country has been passing since the year of 1923. Up to the beginning of that year, a policy of wage deflation and general reduction in costs had been adopted in the attempt to revivify trade and industry and place the country again on a prosperous basis. This procedure was unsuccessful. It was then supplanted by a radical change in constructive attitude.

On the latter Lauck observes (p. 210-11, italics in original omitted):

Stability and regularity of industry mean more to the efficiency of production and therefore more to the rapid accumulation of wealth than any other one thing. And it is in this direction that the greatest strides have been made in the last half dozen years... But higher wages have contributed most of all. They have forestalled strikes, reduced the labor turnover, encouraged employees to more effective work, stimulated loyalty and interest in the business, with the general result of far greater continuity, stability, and therefore, efficiency in industry than ever before.

Who does Lauck cite as major contributors to the "new wage theory" of the 1920s? He shows that a long line of economists, including Adam Smith, John Stuart Mill and Alfred Marshall, promoted a policy of high wages. Lauck, however, gives primary credit to two nonacademic people. One is Henry Ford, who Lauck describes as "the pioneer of the new era as to wage theories" (p. 168); the other is Secretary of Commerce (and later President) Herbert

\footnotetext{
${ }^{14}$ The abandonment that competitive DS wage theory suffered in the 1920s is revealed in the results of a written survey in 1922 of well-known general economists (e.g., Irving Fisher, Frank Taussig, Allyn Young, Thomas Carver), of whom Commons was one, as reported in the Survey (3/11/22: 929). The anonymous author states, "Four [respondents] believed the operation of supply and demand in an open labor market would be sufficient to secure the wage-worker his share of the product; fourteen felt that workers cannot, under modern conditions, secure their full competitive share without collective bargaining; one was doubtful."
} 
Hoover who Lauck (p. 79) claims initiated the "turning point" in the wage revolution in early 1923 with a widely cited speech arguing that economic growth and full employment are promoted by higher wages, not lower wages.

Lauck identifies three distinct components of new era wage theory. They are summarized below. He omits a fourth important component of wage theory (since it was widely known well back into the $19^{\text {th }}$ century) which is also presented here since it provided a central rationale for the New Deal labor program and was subscribed to by both Commons and Keynes.

Living Wage. One component of New Era wage theory was the contention that society should set a floor in the labor market so that wages - or more generally living standards -- cannot go below the subsistence level (where "subsistence" is in part culturally contingent). This subsistence level is called the "living wage" (see Glickman 1997; Stabile 2008).

The living wage rests in part on an ethical/normative argument. That is, although it is socially acceptable for machines to be junked and land to be abandoned if their respective DS prices do not cover their costs, it is not acceptable in a civilized nation to allow the labor input (including dependent spouses and children - the future workforce) to be similarly scrapped and abandoned due to inadequate wages in the labor market. Likewise, it is socially legitimate to put machines and land to work at whatever task will cover their cost but it is illegitimate to have men and women forced into sweatshops, robbery, or prostitution to get the bare necessities of life.

The living wage proposition also has several economic/efficiency rationales. For example, a principle of orthodox economics is that the price consumers pay for a good or service should cover all costs of production. If the market wage is less than the living wage, however, this condition is violated and the unpaid portion of labor cost -- particularly "fixed" labor costs, such as minimum health care, saving for old age, adequate food for children -- are at least in part 
passed on to third parties as a form of negative externality or "social cost" (see Stabile 1993, 2008; Prasch 2005; Kaufman 2010c). ${ }^{15}$ Another possibility is that the unpaid social costs of labor remain partially uncovered; then, however, the nation experiences deterioration in the quantity/quality of its human capital. Given that a worker has a potential productive work life of three-to-four decades, even a short period drop in wages below the subsistence level (with attendant malnutrition, illness, etc.) may have very harmful long-run consequences for the nation's labor supply. ${ }^{16}$ Finally, below-subsistence wages may well precipitate considerable labor conflict and lost production. Capital and land may not protest if they get below-subsistence payment but human workers and their families certainly will, with adverse consequences for not only for the economy but even the political order and survival of capitalism.

Productive Efficiency Wage. Lauck's second component of New Era wage theory is the "productive efficiency" wage. The central idea is that paying a higher-than-market wage, or refraining from cutting wages, may actually generate greater profit for firms because of reduced turnover, greater work effort, stronger employee loyalty and morale, and a stimulus to innovation. ${ }^{17}$ These ideas have been recaptured and formalized in recent years in various versions of efficiency wage theory (Shapiro and Stiglitz 1984; Akerlof and Yellen 1990). Lower productivity and higher costs under the traditional DS wage system come from a variety of sources. Before WWI, for example, many factories had annual employee turnover

\footnotetext{
${ }^{15}$ Industry that does not continually pay a living wage is "parasitic" in that it survives and grows off of a "cost subsidy" from labor (Webb 1912; Kaufman 2010c). To prevent this, Commons argues that social cost "must be assumed by industry as one of the inevitable overhead costs of doing business" (Lewisohn, Draper, Commons, and Lescohier 1925: 153). Firm payments into an unemployment insurance fund are one method to accomplish this. ${ }^{16}$ See Brophy (1964), A Miner's Life, for a vivid account of life at the margin of survival in the 1920s.

${ }^{17}$ On wage cutting, an employer states: "Usually, the first place to start cutting is on wages. That was our last step.... Cutting wages first is the easy road - to nowhere. For the result is the worker's feeling that he has been treated unfairly - which makes him sufficiently inefficient to undo the possible savings on the cost of production. (Johnson, 1921, p. 681). On the link between wages and labor efficiency, another writer states: "As an employer, I would always make the basic wage higher than the current rate in the district, not from any spirit of philanthropy but because of another great principle. Quality, up to a certain point, increases faster than cost.” (Emerson 1922, p. 402.)
} 
rates of 200-to-400 percent and these created substantial hiring, training and separation costs; paying above market wage rates, on the other hand, often reduced turnover by several multiples. Obtaining a stabilized workforce became particularly important after WWI with the widespread adoption of mass production methods. The reason is that that this type of production system has very large sub-process interdependencies and hence poorly trained or missing labor at any point can easily cause large and costly ripple effects up and down the line.

Employers also came to appreciate the importance of employee morale, loyalty and cooperation (Commons 1919; Kaufman 2003c). ${ }^{18}$ They witnessed how the threat of a common foreign enemy and the surge of national patriotism engendered by WWI created a psychological willingness on the part of workers to "go all out" to win the production battle. After the war threat ended, employers sought in the 1920s to replace the energizing effect of national patriotism with "company patriotism." This goal is impossible, however, with the traditional commodity DS model; hence, as earlier described employers turned to a high performance employment model where ILMs partially replace ELMs (external labor markets) and employee loyalty and motivation are energized through mutual gain practices such as job security, in-house promotion, extensive welfare benefits, and fair treatment and opportunities for voice (Moriguchi 2005; Kaufman 2008, 2010b). ${ }^{19}$ A core element of this new ILM model was another mutual-gain practice - fair, stable, and rising wages.

Yet a third source of efficiency and productivity gains from higher wages comes from new technology, additional capital investment, and the inducement upon management to find other areas of cost saving. The DS model of labor suggests that above-equilibrium wages lead to a misallocation of resources and hence an inefficient production mix. But, in New Era thinking,

\footnotetext{
${ }^{18}$ See Solow (1990) and Bewley (1999) for modern evidence and models.

${ }^{19}$ Lauck captures the unique motivational aspect of labor relative to other inanimate factor inputs with the observation, "You can buy an adding machine but you must get cooperation from an accountant" (p. 90).
} 
the true route to national prosperity comes not from low wages but from encouraging human enterprise and innovation. High and rising wages -- up to a point and not overdone -- accomplish this by stimulating employers to develop new products and new technologies, search-out improved organizational and managerial practices, and invest in the most modern machinery, production methods, and employee skills. The positive human-created dynamic efficiency effect of higher wages, therefore, is hypothesized to dominate the negative static allocation effect.

Mass Consumption Wage. A third dimension of the new wage theory of the 1920s discussed by Lauck focuses on workers as consumers and the role of wages as a key determinant of household income, spending, production and full employment. Traditional DS theory draws attention to wages as a cost factor and suggests lower wages promote prosperity by making possible lower production cost and product prices, increased sales to domestic and foreign buyers, and greater satisfaction of consumer wants. The effect of a lower wage (or reduced regulation), ceteris paribus, can be depicted diagrammatically as a rightward shift of a short-run aggregate supply curve along a downward-sloping aggregate demand curve, yielding a win-win outcome of higher GDP and a lower price level. New Era wage theory, on the other hand, argues just the reverse; that is, that prosperity is promoted by high and rising wages and that this works through positive effects on both the demand and supply sides of the economy (that is, both demand and supply curves shift rightward with higher wages). In effect, the new wage theory identifies two "virtuous circles" from higher wages that the orthodox theory neglects.

The first virtuous circle of higher wages is straightforward. The largest source of household income is labor earnings; hence, a higher wage - in conjunction with an inelastic labor demand curve - increases the national wage bill and gives households more income to spend on the products of industry. This consideration - promoting more consumer spending - had not 
hitherto been a significant concern but suddenly the advent of mass production and the emergence of a middle-class consumer society drew attention to the necessity of keeping spending growing apace. Hence, employers suddenly realized that as a class they had a significant self-interest in keeping wages high and rising since absent a balanced increase in spending the economic system would tend toward over-production and stagnation.

The second form of virtuous circle was most famously articulated by Henry Ford and was then picked-up by many others (Meyer 1981). Ford argued that new production technologies, advances in managerial science, and the integration of the nation into a single market had greatly increased the efficient scale of production for most manufacturers. Thus, high and rising wages not only promote higher spending on the demand side but, by doing so, also allow manufacturers to expand output and realize additional cost savings from economies of scale. The virtuous circle, therefore, is that higher wages not only expands consumers' ability to buy more goods and services but also promotes higher volume production, economies of scale, higher labor productivity, and lower product prices. Money wages increase but real wages increase even more with the fall in prices while companies also make more profit from higher volume and lower unit cost. ${ }^{20}$ Diagrammatically, higher wages not only shift the aggregate demand curve rightward but

\footnotetext{
${ }^{20}$ Regarding wages and consumer spending, Ford clearly grasped the multiplier ("ripple") principle per his statement, "It is an ever widening circle of buying and paying a high wage has the same effect as throwing a stone into a still pond." Ford also noted that wages needed to be increased in line with productivity growth to maintain a DS balance, per his remark "If an employer does not share prosperity with those who make him prosperous, then pretty soon there will be no prosperity to share" (quoted in Douglas 1928: 679). Douglas (ibid.) also notes the "free rider" defect in Ford's wage theory, stating: "In the main, therefore, it would be suicidal for individual businesses or industries to increase wages in the hope that they will thereby create an appreciably larger market for their product. Other industries would profit .... whereas the group that increased wages would suffer." He then draws out the policy conclusion that Ford and other New Era industrialists were strenuously trying to avoid and which in turn provided a major reason Douglas and most other institutional economists supported the New Deal labor program. He states, "The [Ford] argument therefore fundamentally implies that either some employers should sacrifice themselves for the benefit of industry as a whole .... or that trade-union pressure and government enactment should be employed to increase the wage scale" (pp. 680-81). Another writer (New Republic 12/4/29: 30) similarly concluded, "An essential instrumentality to carry out the [Henry] Ford policy nationally is a strong labor movement."
} 
also shift the aggregate supply curve rightward - assuming the cost savings from scale economies and other efficiencies more than outweighs the higher payroll costs.

Wages and Destructive Competition. An idea going back to Sismondi (1819) is that in recession and depression situations wage cuts may not restore a demand/supply equilibrium but, instead, precipitate a destabilizing downward wage/price spiral or, in modern terms, "race to the bottom." A similar if more gradual process happens when the extension of markets and development of cheaper production methods puts wages under substantial downward pressure (Commons 1909). Firms and workers experience a significant-sized grinding down of wages and prices as "destructive" and "cutthroat" competition because of the survival of the fittest struggle unleashed and the bankruptcies and poverty left in its wake. A method to forestall destructive competition is to put a floor under the wage structure, such as through industry-wide collective bargaining or a minimum wage law.

The tendency of wages and prices to follow each other downward in a competitive market situation was well recognized in the 1920s and 1930s. For an example, an article in Business Week (4/11/31: 5) states, "It is pointed out that that wage cutting, like price cutting, acts like a snowball. The farther it goes the bigger it gets and the harder it is to stop." Of course, in orthodox theory price and wage cuts are supposed to generate an increase in demand; in actual practice, however, the reverse can happen. A writer in Iron Age (8/6/31: 363) observes, for example, that in normal times lower prices stimulate demand but in recessions/depressions, "price reductions are more likely to discourage large-scale buying than to bring it about. While prices are falling many buyers hold off entirely... with the hope that they may be able to fill their needs later at even lower levels." States another executive, "When prices fall, buyers withdraw from the market" (Literary Digest 6/13/31: 42). The same behavior ripples into labor markets. 
Wage cutting can transition from a market correction to destructive competition when the supply of the good or service involves large fixed costs (both absolutely and relative to variable costs) and involves one or more immobile resources (Kaufman 1997). Rate wars on railroads are a late $19^{\text {th }}$ century example, occurring because large fixed costs and the immobility of the track and roadbed led companies in recessions/depressions to drastically bid down prices in an effort to bring in additional revenue, leading to huge losses and frequent bankruptcies. One response was to put a floor under rates through regulation by the Interstate Commerce Commission.

The example of destructive competition that got the most attention in the 1920s was the bituminous coal industry, frequently labeled a "sick industry" (Bernstein 1960). Plagued with over-capacity and shrinking demand, operators continually shaved prices and then looked for corresponding economies in production. Even when companies went bankrupt the mines often continued to operate but under new owners who bought the properties at distress sale prices, cut wages, and for a short-time at least earned a profit relative to other higher cost producers (Vittoz 1987). Since labor was the largest variable cost component in mining, downward pressure on prices quickly rippled into downward pressure on wages and conditions. During the prosperous 1920s coal miners could escape the downward spiral by leaving the industry for other employments (not costless, however, given mobility constraints, lack of financial resources, and industry-specific skills); after the depression began, however, neither coal miners nor workers across industrial America had an escape option. Hence, the only long-run floor under the wage/price structure is the subsistence wage (i.e., if labor's survival costs are not covered then labor supply shrinks until the wage level rises back to the subsistence level) or revolution. Faced with this lose-lose situation, a coal operator declared in 1931, "the time has come when operators 
will have to seriously consider whether it is better to operate with a well-regulated Union" or to continue competing "with a lot of price-cutting, wage cutting operators" which does not solve the over-supply problem but "fills the mines with Communists" (quoted in Vittoz 1987: 64). ${ }^{21}$

\section{Wage Behavior in the New Era and Great Depression}

The emergence of industrial relations in 1919-1920 signaled a new approach to the employment relationship and management of labor. Instead of a commodity-like "hired hand" labor was now to be treated as a "human resource" partially insulated from short-run demand/supply pressures. The primary purpose was not altruism or union avoidance (since union density fell sharply over the 1920s and never seriously threatened the mass production industries, Nelson 2000); rather, the primary reasons were enhanced efficiency and profit.

Nonetheless, the question remains to what extent the principles of the new wage theory were actually implemented. Several sources of evidence suggest wage behavior did undergo a structural shift post-1921, albeit more so in certain respects than others.

Robert Ozanne in Wages in Theory and Practice (1968) provides data on the money and real wage at the McCormick Works of the International Harvester (I-H) Company for the years 1849-1960, along with money and real wages in the U.S. manufacturing sector. Labor markets were apparently an approximation of a competitive commodity market in the 1860-1890 period, reflected in the significant up and down movement of wages (also see Hanes and James 2003). Starting in the 1890s annual wage variation was smaller, wage cuts were fewer and shallower, and annual wage changes started to exhibit a modest upward asymmetry. Moving to the 1920s and 1930s, Ozanne's data reveal that money wage rates at I-H declined in both the 1920-22 and

\footnotetext{
${ }^{21}$ In the same vein, an anonymous writer states in "Wages Cutting: A Vicious Circle" [New Republic (January 5, 1921, pp. 158-59)], "these vast movements of wages and prices....quite beyond control by human effort....[are] the hope and expectation of the Socialists."
} 
1929-1933 downturns but the wage cuts were deeper and faster in the former. Also, the real wage at I-H fell in the 1920-22 depression but increased each year between 1929 and 1933 (indicating greater proportional rigidity in money wages). Also of relevance, from 1923 to 1929 average hourly earnings in both the US manufacturing sector and at I-H moved upward $(8.4 \%$ and $7.0 \%$, respectively) even as the price level was essentially flat (thus increasing real wages and purchasing power). Closer examination reveals, however, that in the case of I-H ( and also the entire steel industry) the base wage rate actually remained unchanged -- indicating the rise in hourly earnings came from compositional shifts, increased incentive earnings, changes in overtime earnings, etc.-- suggesting these employers were not increasing money wages in a manner consistent with "high wage" and "mass consumption" doctrines.

A similar picture is painted both by people writing at the time of the Great Depression and modern-day economists looking back on the situation. For example, an article published in the finance periodical Bradstreet's Weekly (9/3/32, p. 1121) observed:

Within a few months after production definitely turned down in 1920, wage rates were sharply reduced. Altogether, labor costs were cut 40 percent .... Since 1924, and up to recently, wage rates have held level, and, if anything, moved slightly higher.... With the beginning of the [current] depression.... more than a year after production began its decline did wage-cutting become at all noticeable.... Altogether, wage rates have only fallen 20 percent.

Modern statistical studies of wage behavior in the 1920s-1930s find the same pattern. O'Brien (1989), for example, concludes using the Cagan-Sachs measure of wage flexibility that "money wages were only about one-tenth as flexible after the mid-1920s as before."

The evidence to this point clearly suggests that a structural shift centered on the New Era did affect at least one part of the wage determination process. Employers were noticeably more reluctant to reduce wages in response to slack markets and if forced to cut endeavored to minimize the extent (also see Mitchell 1985). Contemporary observers (e.g., Raymond 1930) 
concluded, however, that much of the talk about raising wages to promote consumer purchasing power spending was empty rhetoric; the evidence cited above supports this proposition.

With regard to wage behavior in the early 1930s, the structural shift is pronounced. After two years of depression the steel industry was operating at less than one-third capacity and red ink was starting to gush yet the companies held the line on wage rates. Labor historian David Brody (1980) concludes that if the depression had ended in 1931 the welfare capitalist employers would have been lauded for their progressive employment practices and humane treatment of labor. As it was, even the mightiest corporations finally succumbed to wage cutting - perhaps seen by economists as a triumph of demand/supply and sound economics but viewed by business people as "a defeat for modern management" (Business Week (6/6/31: 52) and the beginning of a disorderly retreat to a more primitive and less productive economy. The depression did not end in 1931 but worsened and hit bottom only in March 1933. O'Brien reports in his study that during the first seventeen months of the Great Depression wage rates only declined by about 2 percent. One concludes that the New Era "structural shift" in wage determination was successfully holding the line on wage reductions. But then O'Brien observes that in the final eighteen months of the downturn wage rates declined by more than 25 percent.

The defining moment came in September, 1931 when the market forces of deflation finally forced U.S. Steel to announce a ten percent wage cut. Other steel firms announced identical pay cuts the same day and soon copper, auto, and tire companies followed suit. Wage cutting rapidly spread across the labor market; then later in 1932 U.S. Steel announced further large cuts (e.g., 15\%), setting off more rounds of reductions in a worsening downward spiral.

Opinion was sharply divided on the wisdom and final effects of the wage cuts. Pressure for wage cuts, according to one business periodical (Iron Age, 6/18/32, p. 1998), came primarily 
from "bankers and theoretical economists" and they reacted favorably. So too did the stock market which rose on the announcement of the first steel wage cut. Early in the depression Secretary of the Treasury Andrew Mellon, a member of the deflationsist school, said the cure to the depression was to "liquidate labor, liquidate stocks, liquidate farmers, liquidate real estate...." with the idea that a fall in prices and wages would bring markets back to equilibrium (quoted in Sobel 1975: 56). On the other side were many people, including large segments of the non-financial business community, who said the wage cuts would only worsen the slump and further embitter employment relations. For example, Business Week (10/7/32: 6) editorialized:

To risk satisfactory employee relationships, maintained only with considerable difficulty under present conditions, for a wage cut which can have only a minor effect upon costs at the best and is just as likely to increase them as to lower them appears to many managers with modern views on employee relationships a gamble against reasonable odds.

The editorial writer goes on to add in the next sentence, "But if business improves, they [the skeptics of wage reduction] are answered." It is instructive to note for the next section on New Deal labor policy that, in fact, the rolling series of wage reductions were followed by another year and one-half of deepening depression -- directly opposite the predictions of DS theory. It appeared, therefore, that competitive theory was given its chance to work and clearly failed.

\section{Hoover, FDR, and the New Deal Labor Program}

As noted in the literature review, a growing number of economists blame Hoover, Roosevelt and the New Deal for the severity and length of the Great Depression. The discussion of Commons and Keynes and the New Era institutional wage theory provides the theoretical foundation for a rebuttal and counter-argument; the only task remaining, therefore, is to draw the threads together.

I first cover the stable wage part of the Hoover/FDR economic program and then take a more detailed look at the three major pieces of New Deal labor legislation. 
Ohanian (2009), Rothbard (1972), and like-minded economists claim both Hoover and FDR practiced bad economic policy and made the downturn much worse by trying to maintain wage rates. A labor market is (in this view) like every other market and if supply exceeds demand the wage rate needs to fall until equilibrium ("full employment") is restored. Either because they did not understand elementary economics, or because they "sold-out" to special interest groups (e.g., unions), both Hoover and Roosevelt did just the opposite and lobbied to prevent wage cuts. Illustratively, shortly after the depression began Hoover called a high profile group of businessmen to the White House and persuaded them to publicly commit their companies to holding the line on wage rates (Hoover 1952; Rothbard 1972). Much better, say orthodox economists, had he persuaded them to quickly cut wages (Romasco 1983: 19-21). Now consider the institutional/Keynesian side of the argument. Both Hoover and FDR built their wage programs on the New Era wage theory (Sobel 1975; Himmelberg 2001; Rosenof 1983). If its tenets are accepted and then an economic depression begins, what would logically follow as the policy response? Clearly it would be broadly consistent with exactly what Hoover and Roosevelt did.

That is, Hoover and Roosevelt knew that the depression was a problem of inadequate demand, as Ford could easily produce more Model T's but had few customers with enough income to buy them (Rosen 1977; Temin 2007). Seen in this light, it appeared to Hoover and Roosevelt counter-productive and wrong-headed to press Ford and other employers to cut wages with the idea that their workers/customers would then walk in and buy more of their products even if the prices are marked-down (Fusfeld 1956). Of course, it is not the wage rate per se that determines household income, as total employment and hours of work also count, but Hoover, Roosevelt and their advisors believed, probably correctly (Hamermesh 1993), that labor demand 
is in general inelastic -- and probably quite so in a depression situation -- and therefore wage cuts reduce the aggregate wage bill. Wage maintenance therefore makes sense from a spending perspective (Rosenof 1975; Romasco 1983).

Both Presidents also thought that a large contributor to the New Era prosperity of the United States was the labor peace and rapid productivity growth made possible by the new “goodwill” industrial relations system (Barber 1985; Gordon 1984). They surmised, therefore, that wage cutting -- and all the other give-backs that inevitably follow (e.g., speed-ups, harsher treatment) -- would not only quickly destroy the expensive and difficult-to-recreate human capital investment built up over the previous decade but also unleash labor unrest, strikes and militant union campaigns -- and all for no gain in jobs or production! Here again wage maintenance makes good sense. When contemplating what do with wages, both Presidents also quickly realized that what they did not want to do was turn the nation into a macroeconomic example of the coal industry in which wage cuts and destructive competition unleash a deflationary race to the bottom that impoverishes and then bankrupts millions of families and companies (Vittoz 1987). And, finally, both Presidents could see the human wreckage and social costs that arise from things such as homelessness, malnourishment, and child labor when wage cuts lower families' income below the bare survival level (Sobel 1975; Fusfeld 1956).

Thus, for all these reasons, which appear to be logical deductions derived from reasonable premises and therefore "good economics," both Hoover and FDR opted for stable wages. It may also be noted, contrary to the claim of Ohanian (2009), that Hoover did not arm twist reluctant employers to forego wage cuts since the major corporations were already committed to stable wages as part of their profit maximizing human resource strategy (Bernstein 
1960; Ozanne 1968; Kaufman 2008). Further, if Hoover was a hand-maiden of union's interests then he would have adopted their \#1 recovery measure - a 30 hour work week (Far 1959).

Let us now shift attention to the New Deal labor program. First note that both Commons and Keynes supported it, at least in broad outline. This is hardly surprising in the case of Commons, given that he was identified in the news media at the time as "Prophet of the New Deal" and "Father of Brain-Trusting" (Kaufman 2003c) and had lobbied for two decades and more for stronger protective labor law, expanded collective bargaining, and creation of a safety net of social insurance programs. As for Keynes, he wrote an open letter to FDR published in the New York Times (12/31/33, reprinted in Moggridge, 1982, Vol. 21) and states:

You have made yourself the trustee for those in every country who seek to mend the evils of our condition by reasoned experiment within the framework of the existing social system. If you fail, rational change will be gravely prejudiced throughout the world, leaving orthodoxy and revolution to fight it out. But if you succeed.... we may date the first chapter of a new economic era from your accession to office (p. 289).

On FDR's labor program, Keynes declared, "I regard the growth of collective bargaining as essential. I approve minimum wages and hours regulation" (Moggridge 1982, Vol. 21: 438).

The three central pieces of New Deal labor legislation are the National Labor Relations Act (NLRA), Fair Labor Standards Act (FLSA), and Social Security Act (SSA). Mention must also be made of the National Industrial Recovery Act (NIRA) because portions of it were a forerunner to the NLRA and FLSA. The NLRA encouraged and institutionalized collective bargaining and banned non-union representation plans ("company unions"), the FLSA established laws setting a federal minimum wage, an overtime pay requirement, and ban on child labor; and the SSA created a federal old age pension plan and federal-state unemployment insurance system (Bernstein 1970; Gordon 1994). These laws were enacted in 1935-1938; the 
economy had started to recover but was by any measure still mired in depression (e.g., unemployment was between 15 and 20 percent) and, indeed, suffered a relapse in 1938 .

The central question is: were these three labor laws good or bad economic policy? From the perspective of DS economics only one answer is possible - bad and terribly timed. All three substantially increased the price of labor, raised business operating cost, and diminished incentives to work -- in the middle of a depression. From a Real Business Cycle perspective, all cause a large negative supply shock and contraction in output and employment.

Now examine this matter through the prism of New Era wage theory. The task is to stop destructive competition, expand purchasing power, contain growing labor radicalization and conflict, and keep labor conditions and living standards from falling below the social minima. Commons and Keynes both looked to monetary/credit policy as the first-line policy instrument for stabilizing aggregate demand (Whalen 1993; Atkinson and Oleson 1998; Skidelsky 2009). But it had clearly failed in the early part of the depression, partly because adherence to the orthodox gold standard - called by Keynes a "barbarous relic" (quoted in Moggridge, Vol. 20: 161) - induced the Federal Reserve to perversely raise interest rates and contract money growth (Eichengreen, in Parker 2007: 141-42). With the economy deep in depression and banks hoarding excess reserves, it appeared that expansionary monetary policy and lower interest rates were no longer much effective. To the dismay of DS fundamentalists, Roosevelt quickly abandoned the gold standard once in office but by this point expansionary monetary policy was too much of "pushing on a string" (Romer 1993; Bernanke 2000).

Commons and Keynes also favored counter-cyclical deficit spending but here too was a large problem. Both Hoover and Roosevelt opposed budget deficits and FDR in particular used this option in his first term as sparingly as political pressure would allow (Himmelberg 2001). 
With an impotent domestic monetary tool, an anemic fiscal tool, and an uncertain foreign

exchange tool, Commons and Keynes, along with FDR and all his advisors (Rosen 1977), had to look for other options to stop the downward plunge and spur recovery.

One option was to let wages/prices fall more and trust that recovery automatically starts via the economy's self-regulating mechanism. However, as Keynes famously remarked "We are all dead in the long run" and it looked to him and many other observers that when FDR took office in early 1933 the "long-run" was starting to shrink to a matter of months if deflation and contraction continued on their downward spiral (Skidelsky 1983: 490).

FDR had to act fast and he pushed Congress to enact in June 1933 the NIRA. From a Commons/Keynes perspective, the NIRA had both good and bad parts. One good part is that it quickly reversed the deflationary expectations that were dragging the economy downward and jump-started a rebound in production, employment and optimism (Skidelsky 1983: 490; Eggertsson 2008). Another beneficial part were measures to stabilize wages, such as the famous Section 7(a) provision forbidding employers from interfering with workers' rights to collective bargain and a provision mandating minimum wages (Far 1959; Gordon 1994). And, finally, upon the insistence of Senator Robert Wagner the NIRA also included over three billion dollars for public works spending. The bad part, which Keynes detailed in a letter to FDR (Moggridge 1982, Vol. 21: 291), was allowing industry associations to fix prices and cartelize product markets in an effort to stop price deflation. This part was restrictive, not expansionary, and was unnecessary since stabilizing the wage structure effectively stabilizes the price structure. A number of institutional economists, particularly from the Veblenian "planning" wing of the field, favored the NIRA as a move toward European style "corporatism" (management of the economy by organized interest groups), economic planning, and "industrial self government" (Balisciano 
1998; Rutherford and Desrcohes 2008). Commons, however, was not in favor of the corporatist side of the NIRA. He favored where possible market and voluntarist arrangements and promoted collective action solutions that were more "bargained" (mutual consent, as opposed to "managerialist" or "commanded") and decentralized (Commons 1934, Ch. 11).

The NIRA was declared unconstitutional in June 1935 (Far 1959; Gordon 1994). The unemployment rate had come down but was still near 20 percent (excluding people on New Deal make work projects); also, the public relief and job creation programs were under-funded relative to the massive poverty and human suffering after five years of depression. So, again, FDR had to come up with a policy response to keep recovery going and rebuild the social minima.

This brings us to the trilogy of NLRA, FLSA and SSA. In effect, the NLRA and FLSA restored and strengthened the wage stabilization/recover program contained in the NIRA (Mitchell 1984; Gordon 1994; Kaufman 1996). The NIRA's Section 7(a) protection of collective bargaining rights was strengthened via a set of proscribed unfair labor practices, the creation of a secret ballot union representation procedure, and a new regulatory agency to o versee the law. The FLSA similarly strengthened the NIRA's minimum wage provision so now it covered most of the workforce and was mandatory (rather than negotiated); the FLSA also did the same with overtime pay and banishment of child labor. The SSA was the new piece of the labor program, as the NIRA had no social insurance component.

These three bills are not commonly viewed in the IR literature as directly serving a macroeconomic purpose. Frances Perkins, Roosevelt's Labor Secretary, clearly states otherwise, however, and in almost classic form for the thesis of this paper (quoted in Craypo 1997: 226):

As a nation, we are recognizing that programs long thought of as merely labor welfare, such as shorter hours, higher wages, and a voice in terms and conditions of work, are really essential economic factors for recovery and for the technique of industrial management in a mass production age. 
In particular, the NLRA was intended to promote recovery by (1) putting a floor via collective bargaining on wages and conditions, thus stopping destructive competition; (2) augmenting purchasing power and aggregate demand by raising wages and keeping them in line with productivity growth and the cost of living; and (3) institutionalizing union recognition and bargaining and thus ending a potent source of strikes and embittered relations (Mitchell 1984; Kaufman 1996). The NLRA also banned employee representation plans (company unions) because, in Wagner's view, although they often improved internal workplace relations they nonetheless were a threat to the New Deal's wage-led recovery program (Kaufman 2000). The FLSA had much the same economic purpose and, indeed, was portrayed as an alternative form of "collective bargaining" for unorganized workers and in industries/states with small union coverage (Linder 1989; Craypo 1997). Besides raising wages for the lowest paid and creating a wage floor across labor markets, the FLSA also sought to curb other forms of destructive competition and social exploitation by restricting long work hours and child labor.

The SSA created old age pensions and federal-state programs of unemployment insurance. The old age pension program was part a reform effort to set a social minima for retired workers and their families. It was also expressly adopted to promote greater purchasing power via a regressive tax/benefit schedule that on balance redistributed income from the top tier to the low-to-middle tier (Graebner 1980). In the short-run, however, it may have actually had a contractionary effect as payroll taxes increased faster than benefit payments. The unemployment insurance part of SSA also had a foundation in New Era wage doctrines (Commons 1923a). For example, it provides a living wage during periods of unemployment, stabilizes household income so unemployed workers have partial support for necessities and mortgages, makes recessions 
shallower by reducing the size of the Keynesian spending multiplier, and provides an incentive for firms to stabilize employment and payrolls (Altman 2004).

Three additional observations are required before ending. First, it is indisputable that the New Deal labor policies, most particularly the NLRA and Section 7(a) of the NIRA and the union organizing and mass strikes that accompanied them, created a negative supply shock that (ceteris paribus) retarded recovery. Sit-down strikes don't contribute to higher auto production. As with every other part of the critic's case, however, there is another side to the story.

Commons' Legal Foundations of Capitalism (1924) describes how excluded and oppressed groups, beginning in the twelfth-century when the English feudal lords wrested the Magna Carta from tyrannous King John, have in various violent and peaceful ways challenged the established power structure to gain greater political rights, voice, and share of the economic pie. From an institutional perspective, the labor uprising of the 1930s was the next chapter in this story as masses of workers, supported by a sympathetic Democratic administration, stood-up against an autocratic form of industrial government where employers exercised monarch-like powers and workers were given no more legal protections in labor markets than were commodities in product markets. Likewise, in this view part of the cause of the Depression was an unbalanced economic system with a skewed structure of income and wealth, political power, property rights, and management prerogatives and, accordingly, structural reform became a prerequisite for recovery and lasting prosperity. This theme is stated in the Preamble to the NLRA which ties the depression to lack of broad-based purchasing power resulting from labor's inequality of bargaining power (Mitchell 1984; Kaufman 1996). Therefore, the New Deal can be considered a double gain - it laid the foundation for economic recovery from the depression and 
a three decade era of shared economic growth and it brought to the American labor market and workplace a much-needed expansion of industrial democracy (Derber 1970).

The second observation is that questions may certainly be raised about the efficacy and wisdom of parts of the New Deal labor program. With the advantage of hindsight, one can doubt that a wage-led recovery strategy is the most efficacious approach to ending a depression. As already pointed out, however, complete economic collapse appeared dangerously close and other policy instruments seemed foreclosed or of doubtful effectiveness. Also, the rationale for a wage-led recovery came from a widespread conviction that an important cause of the depression was an under-consumption problem caused by the growing inequality of income and wealth during the 1920s (Rosenof 1975; Mitchell 1984; Kaufman 1996).

Although the income distributions argument is almost completely ignored/dismissed by modern economists (e.g., Romer 1993; Parker 2007: 115), Roosevelt, Wagner and many others believed maldistribution was the primary structural explanation for the slump (Fusfeld 1956; Rosenof 1975). ${ }^{22}$ Here, interestingly, arose a major cleavage in the New Deal coalition. Those who believed income inequality and under-consumption were the primary cause of the depression also tended to favor more radical forms of planning, restructuring and redistribution, including industry-wide unionism (Kuhn 1988; Balisciano 1998). Commons and Keynes were not in this group, however. They both favored policy measures to reduce income inequality but pinpointed monetary and credit problems as the primary cause of the depression (Commons 1934: 793, 804; Keynes 1936: 372; Whalen 2008b). They also had a philosophical commitment

\footnotetext{
${ }^{22}$ There were different theories of under-consumption at the time (McCracken 1933; Kuhn 1988); Commons and Keynes rejected Hobson's over-investment version but did give more credence to the failure of prices to fall and real wages to grow in line with productivity growth, presumptively due to monopoly power in product markets (Commons 1923b; 1937). The post-1980 period also features rising productivity, stagnant real wages, and soaring income inequality (from 1976-2007, 58\% of real income gains went to the top $1 \%$ of the households, reported in Financial Times, July 14, 2010: 7). The link between rising income inequality and aggregate demand remains, however, a heterodox and mostly invisible subject in the mainstream U.S. economics literature.
} 
to market-ordering and voluntarism (Adelstein 1991; Atkinson and Oleson 1998) and gave greater recognition to the negative supply side effect of unions on productivity and innovation (Milnow 1992; Commons 1911; Kaufman 2003a).

Many modern IR writers (e.g., Kochan, Katz, and McKersie 1986) take it as a "given" that the NLRA and its encouragement of unionism was the foundation stone of New Deal labor policy. As this discussion illustrates, however, there was actually widespread division in the New Deal coalition over the efficacy of unions as a means to promote economic recovery and industrial democracy. ${ }^{23}$ Some New Dealers, such as William Leiserson (NLRB chair), swung over firmly to the cause of industry-wide unionism, per his remark "the organization of labor and collective bargaining [are] necessary and inevitable" (Leiserson 1938: 43), but Labor Secretary Frances Perkins took the opposite side, per her remark "I would rather pass a law then organize a union" (Wandersee 1993). Part of this controversy rested on the pros and cons of using widespread collective bargaining to jump-start economic recovery and promote long-term prosperity. This idea was highly controversial in the 1930s and is not mentioned today as a possibility by mainstream economists writing on unions (see Addison and Schnabel 2003; Bennett and Kaufman 2007). Yet, with monetary policy of limited effectiveness in today's economy and fiscal policy forced toward budget-balancing, perhaps the nation will have to once again consider a wage-led recovery - even perhaps through expanded collective bargaining.

\section{Conclusion}

\footnotetext{
${ }^{23}$ The dour opinion on the labor movement among even committed New Dealers is revealed in this reminiscence by Thomas Eliot, assistant legal counsel in the Labor Department. He recalls: "While I was all for upholding workers' rights under Section 7(a).... I was not automatically pro-union. Far from it. Frequently I wrote [family members] scornfully about the leaders of some of the major A.F. of L. craft unions.... calling them 'a bunch of racketeers in league with a lot of the building contractors'.... I'd like to see equality of bargaining power, but I doubt the efficacy of any program designed to increase the strength of the A.F.of L. as presently constituted" (Eliot 1992: 56-57).
} 
Institutional economist and Brains Trust member Rexford Tugwell (quoted in Walton and Rockoff 2005: 469) remarked on the 1930s, "The Cat is out of the bag. There is no Invisible Hand. There never was. If the depression has not taught us that, we are incapable of education." Apparently at least a portion of modern-day economists are indeed "incapable of education" for over several decades a growing number have been pushing anew the orthodox mantra that wage rigidity caused or much worsened the Great Depression and the "high wage" New Deal labor program then further lengthened the downturn. Hence, the lessons inculcated are "government is part of the problem," "let free markets work," and "unemployment is an individual choice."24

These are appealing and persuasive ideas for anyone schooled in the theory of demand and supply and to deny them seems a sure sign it is the critic that is "incapable of education." The purpose of this paper has been to challenge the orthodox position on both counts. To do so I have examined the position of John Commons and J.M. Keynes on the causes of the Great Depression, the desired policy on wages, and the pros and cons of the New Deal labor program. Both men supported wage maintenance, as did many other economists of that era. They did so for both theoretical and normative reasons. The theoretical reason is that wage cuts do not cure generalized unemployment and, if anything worsen the situation. Orthodox DS economists fail to see this because, first, they ignore (per Keynes) the negative effect wage cuts have on total spending and employment (by conflating via the fallacy of composition micro DS conclusions with macro behavior) and, second, ignore (per Commons) the negative effect wage cuts have on the employment relationship and production/supply side of the economy (because they model

\footnotetext{
${ }^{24}$ Albert Rees (1970), commenting on the "unemployment is disguised leisure" argument of Lucas and Rapping (1969), states: "Though scientific discussion is supposed to be dispassionate, it is hard for one old enough not to regard as monstrous the implication that the unemployment of that period could have been eliminated if only all the unemployed had been more willing to sell apples or to shine shoes" (p. 308). Clark Kerr (1988) offers a similar assessment: "[O]ur hardworking neighbors and friends, through no fault of their own, were sold out, down to the family dog going to a stranger for a dime. These farmers were not seeking leisure or going on a job search.... What happened to them was totally involuntary" (p. 6).
} 
workers as a commodity and firms as technical production functions). Had labor markets in the Great Depression actually functioned akin to competitive commodity markets the certain result is that the economic collapse would have been even more catastrophic - illustrated by the fact that the downturn only worsened after wages started their downward plunge in the fall of 1931 . With government on the sidelines and DS running amuck, the wage/price structure and overall economy would surely have further slumped had Roosevelt and the New Deal not intervened. ${ }^{25}$ Commons (1950) encourages economists to utilize a broader and more "human oriented" theoretical framework and take a more pragmatic perspective on policy. He states:

Interference with the law of supply and demand has always been the main objection raised against all collective action, whether against protective tariffs, against immigration restriction, against labor unions, or against corporations; but these interferences have nonetheless been repeated and cumulated for a hundred years, because the alternatives of noninterference under the circumstances were deemed worse than the interferences. Public programs and policies cannot be evaluated in terms of logical consequences of isolated assumptions or similarities. They must be judged by the practical consequences of their operations. This requires a subtle balancing of many parts - some of which are necessarily contradictory (p. 137, italics in original).

Since commitment to DS principles and the Invisible Hand idea are deeply ingrained in economists, moving beyond them is not easy -- per Keynes' (1936) statement that for him it took, "a long struggle of escape.... from habitual modes of thought and expression" (p. viii). It is important to make this escape, however, since simplistic DS theorizing leads to seriously inaccurate diagnoses of the cause of economic problems and policy solutions thereto. Among the latter is blaming government, unions, and industrial relations practices for interfering in competitive labor markets and causing macroeconomic problems. The institutional/Keynesian view is that all three, even though imperfect, are essential to capitalism's survival and growth.

\footnotetext{
${ }^{25}$ According to Keynes, "Individualistic capitalism simply cannot stand a declared policy of deflation" (Milnow 1992: 502) and "[I]f the theory that underlies all this [wage cutting] is to be accepted, the end will be that no one can be employed except those happy few who grow their own potatoes" (quoted in Dillard 1983: 217).
} 


\section{References}

Addison, John, and Claus Schnabel. 2003. International Handbook of Trade Unions. Northampton: Elgar.

Adelstein, Richard. 1991. “"The Nation as an Economic Unit': Keynes, Roosevelt, and the Managerial Ideal,” Journal of American History, Vol. 78, No. 1, pp. 160-87.

Akerlof, George, and Janet Yellen. 1990. “The Fair Wage-Effort Hypothesis and Unemployment," Quarterly Journal of Economics, Vol. 105 (May), pp. 255-84.

Altman, Morris. 2004. Why Unemployment Insurance Might Not Only Be Good for the Soul, It Might Also Be Good for the Economy, Review of Social Economy, Vol. 62, No. 4, p. $517-41$.

Atkinson, Glen, and Theodore Oleson Jr. (1998) "Commons and Keynes: Their Assault on Laissez-Faire,” Journal of Economic Issues, Vol. 32 (December), pp. 1019-30.

Balisciano, Marcia. 1998. "Hope for America: American Notions of Economic Planning Between Pluralism and Neoclassicism, 1930-1950.” In Mary Morgan and Malcolm Rutherford, eds., From Interwar Pluralism to Postwar Neoclassicism, pp. 153-78. Durham, NC: Duke University Press.

Barber, William. 1985. From New Era to New Deal: Herbert Hoover, the Economists, and American Economic Policy, 1921-1933. New York: Cambridge University Press.

Basset, William. 1922. "How Low Prices Can Pay High Wages," Collier's (November 25), pp. 11-12.

Bennett, James, and Bruce Kaufman. 2007. What Do Unions Do? A Twenty Year Perspective. 
New Brunswick, NJ: Transaction.

Bernanke, Ben. 2000. Essays on the Great Depression. Princeton: Princeton University Press.

Bernstein, Irving. 1960. The Lean Years: A History of the American Worker, 1920-1933. Boston: Houghton-Mifflin. 1970. The Turbulent Years: A History of the American Worker, 1933-1941. Berkeley: University of California Press.

Bewley, Truman. 1999. Why Wages Don't Fall During a Recession. Cambridge, MA: Harvard University Press.

Brody, David. 1980. Workers in Industrial America: Essays on the Twentieth Century Struggle. New York: Oxford University Press.

Brophy, John. 1964. A Miner's Life: An Autobiography. Madison: University of Wisconsin Press.

Calomiris, Charles. 2007. "A Raw Deal: Reconsidering the Great Depression," Foreign Affairs, Vol. 86, No. 5, pp. 141-46.

Chari V., Patrick Kehoe, and Ellen McGrattan. 2003. “Accounting for the Great Depression,” Federal Reserve Bank of Minneapolis Quarterly Review, Vol. 27, No. 2, pp. 2-8.

Chasse, Denis. 1991. “John R. Commons and John Maynard Keynes: Two Philosophies of Action," Journal of Economic Issues, Vol. 25, No. 2, pp. 441-48.

Commons, John. 1909. “American Shoemakers, 1648-1895,” Quarterly Journal of Economics, Vol. 24, No. 4, pp. 39-83. 
. 1911. "Unions and Efficiency," American Economic Review, Vol. 1, No. 3, pp.

463-72.

.1919. Industrial Goodwill, New York, McGraw-Hill.

. 1921a. "Industrial Relations." In J. Commons, ed., Trade Unionism and Labor

Problems, $2^{\text {nd }}$ series. Boston: Ginn (reprinted by Augustus Kelly, 1967), pp. 1-16.

. 1921b. Industrial Government. New York: Macmillan.

. 1923a. "Unemployment - Prevention and Insurance." In L. Edie, ed., Big Business:

Economic Power in a Free Society, pp. 164-205. New York: Macmillan.

. 1923b. "Hobson's 'Economics of Unemployment'," American Economic Review, Vol.

13, No. 4, pp. 638-47.

. 1923c. Wage Theories and Wage Policies," American Economic Review, Vol. 13, No. 1, pp. 110-17.

1924. The Legal Foundations of Capitalism. New York: Macmillan

. 1925. "Marx Today: Capitalism and Socialism," Atlantic Monthly, Vol. 136

(November), pp. 682-93.

. 1934. Institutional Economics: Its Place in Political Economy. New York, Macmillan.

1937. "Capacity to Produce, Capacity to Consume, Capacity to Pay Debts," American

Economic Review, Vol. 27, No. 4, pp. 680-97.

. 1950. The Economics of Collective Action. Madison, WI: University of Wisconsin 
Press.

Cowdrick, Edward. 1930. "Dulling the Ax of Dismissal," Nation's Business (October 1930), pp. 47-49, 212-13.

Craypo, Charles. 1997. “Alternative Perspectives on the Purpose and Effects of labor Standards Legislation." In Bruce Kaufman, ed., Government Regulation of the Employment Relationship, pp. 221-51. Madison: Industrial Relations Research Association.

Crotty, James. 1990. “Keynes on Stages of Development of the Capitalist Economy: The Institutional Foundation of Keynes’ Methodology,” Journal of Economic Issues, Vol. 24, No. 3, pp. 761-80.

Davidson, Paul. 2007. John Maynard Keynes. New York: Palgrave Macmillan.

Davis, J. Ronnie. 1971. The New Economics and the Old Economists. Ames, IA: Iowa State University Press.

Derber, Milton. 1970. The American Idea of Industrial Democracy. Champaign-Urbana: University of Illinois Press.

Dessing, Maryke. 2002. Labor Supply, the Family and Poverty: The S-Shaped Labor Supply Curve," Journal of Economic Behavior and Organization, Vol. 49, No. 4, pp. 433-58.

Dillard, Dudley. 1946. “The Pragmatic Basis of Keynes’s Political Economy,” Journal of Economic History, Vol. 6 (November), pp. 121-52.

Douglas, Paul. 1928.'The Modern Technique of Mass Production and Its Relation to Wages," Proceedings of the Academy of Political Science, Vol. 12 (1926-1928), pp. 663-88. 
Eggertsson, Gauti. 2008. "Great Expectations and the End of the Depression," American Economic Review, Vol. 98, No. 4, pp. 1476-1516.

Eliot, Thomas. 1992. Recollections of the New Deal: When the People Mattered. Boston: Northeastern University Press.

Emerson, Harrington. 1922. "Wages," Chemical and Metallurgical Engineering (August 30), pp. 400-03.

Far, Grant. 1959. The Origins of Recent Labor Policy. Boulder: University of Colorado Press.

Fusfeld, Daniel. 1956. The Economic Thought of Franklin D. Roosevelt and the Origins of the New Deal. New York: Columbia University Press.

Galloway, Lowell. 2010. “Unions, the High-Wage Doctrine, and Employment," Cato Journal, Vol. 30, No. 1, pp. 197-213.

Glickman, Lawrence. 1997. A Living Wage: American Workers and the Making of Consumer Society. Ithaca: Cornell University Press.

Gordon, Colin. 1994. New Deals: Business, Labor, and Politics in America, 1920-1935. New York: Cambridge University Press.

Graebner, William. 1980. A History of Retirement: The Meaning and Function of an American Institution. New Haven: Yale University Press.

Grayson, Carmen. 1975. W. Jett Lauck: Biography of a Reformer. Charlottesville, VA: University of Virginia Press. 
Groshen, Erica, and Mark Schweitzer. 1997. "Macro-and Microeconomic Consequences of Wage Rigidity.” In D. Lewin, D. Mitchell, and M. Zaidi, eds., The Human Resource Management Handbook, Part 1, pp. 217-49. Greenwich, CT: JAI.

Hamermesh, Daniel. 1993. Labor Demand. Princeton: Princeton University Press.

Hanes, Christopher, and John James. 2003. "Wage Adjustments under Low Inflation: Evidence from U.S. History," American Economic Review, Vol. 93, No. 4, 1414-23.

Hansen, Alvin. 1923. "The Outlook for Wages and Employment," American Economic Review, Vol. 13, No. 1, pp. 27-44.

Hicks, Clarence. 1941. My Life in Industrial Relations. New York: Harper \& Bros.

Himmelberg, Robert. 2001. The Great Depression and New Deal. Westport: Greenwood.

Hoover, Herbert. 1952. The Memoirs of Herbert Hoover, Vol. 2. New York: Macmillan.

Jacoby, Sanford. 1985. Employing Bureaucracy: Managers, Unions, and the Transformation of Work in American Industry, 1900-1945. New York: Columbia University Press. . 1997. Modern Manors: Welfare Capitalism Since the New Deal. Princeton: Princeton University Press.

Johnson, George. 1921. “What I've Learned About Business Since 1920," System, Vol. 15, No. 6, pp. 679-83, 728-30.

Kates, Steven. 1998. Say's Law and the Keynesian Revolution, Northampton: Elgar. . 2008. "A Letter From Keynes to Harlan McCracken Dated 31 ${ }^{\text {st }}$ August 1933: Why the 
Standard Story on the Origins of the General Theory Needs to be Rewritten," History of Economics Review, Vol. 47 (Winter), pp. 39-53.

Kaufman, Bruce. 1996. "Why the Wagner Act? Reestablishing Contact with Its Original Purpose.” In D. Lewin, B. Kaufman, and D. Sockell, eds, Advances in Industrial and Labor Relations, Vol. 7, pp. 15-68. Greenwich, CT: JAI Press.

1997. "Labor Markets and Employment Regulation: The View of the 'Old Institutionalists." In B. Kaufman, ed., Government Regulation of the Employment Relationship, pp. 11-55. Madison: Industrial Relations Research Association. . 2000. "The Case for the Company Union," Labor History, Vol. 41, No. 3, pp. 321-50. . 2003a. "Industrial Relations Counselors: Its History and Significance." In Bruce Kaufman, Richard Beaumont and Roy Helfgott, eds., Industrial Relations to Human Resources and Beyond: The Evolving Process of Employee Relations Management, pp. 31-112. Armonk: M.E. Sharpe. . 2003b. "The Quest for Cooperation and Unity of Interest in Industry,” In Bruce Kaufman, Richard Beaumont and Roy Helfgott, eds., Industrial Relations to Human Resources and Beyond: The Evolving Process of Employee Relations Management, pp. 115-46. Armonk: M.E. Sharpe. .2003c. "John R. Commons and the Wisconsin School on Industrial Relations Strategy and Policy," Industrial and Labor Relations Review, Vol. 57, No. 1, pp. 3-30. . 2004. The Global Evolution of Industrial Relations: Events, Ideas and the IIRA. 
Geneva: International Labor Organization.

. 2008. Managing the Human Factor: The Early Years of Human Resource Management in American Industry. Ithaca, NY: Cornell University Press.

. 2010a. "The Theoretical Foundation of Industrial Relations and Its Implications for Labor Economics and Human Resources," Industrial and Labor Relations Review, Vol. 64, No. 1, pp. 817-851. . 2010b. Hired Hands or Human Resources? Case Studies of Human Resource Programs and Practices in Early American Industry. Ithaca, NY: Cornell University Press. .2010c. "Institutional Economics and the Minimum Wage: Broadening the Theoretical and Policy Debate," Industrial and Labor Relations Review, Vol. 63, No. 3, pp. 427-53.

Keynes, John. 1936. The General Theory of Employment, Interest, and Money. London: Harcourt Brace.

King, William. 1918. Industry and Humanity. Toronto: University of Toronto Press.

Kochan, Thomas, Harry Katz, and Robert McKersie. 1986. The Transformation of American Industrial Relations. New York: Basic Books.

Krugman, Paul, and Robin Wells. 2009. Macroeconomics, $2^{\text {nd }}$ ed. New York: Worth.

Kuhn, Rick. 1988. "Labour Movement Economic Thought in the 1930s: Underconsumptionism and Keynesian Economics," Australian Economic History Review, Vol. 28, No. 2, pp. 5374.

Lauck, W. Jett. 1929. The New Industrial Revolution and Wages. New York: Funk \& Wagnalls. Lavoie, Marc. 1992. Foundations of Post-Keynesian Economic Analysis. Northampton: Elgar. 
Lawler, Edward. 1992. The Ultimate Advantage: Creating the High-Involvement Organization. San Francisco: Jossey-Bass.

Lee, Frederick, and Warren Samuels. 1992. The Heterodox Economics of Gardiner C. Means: A Collection. Armonk: M.E. Sharpe.

Leiserson, William. 1938. Right and Wrong in Labor Relations. Berkeley: University of California Press.

Levendis, John. 2007. “The Fallacy of Wage Cuts and Keynes’ Involuntary Unemployment,” Journal of the History of Economic Thought, Vol. 29, No. 3, pp. 309-29.

Lewisohn, Sam, Ernest Draper, John Commons, and Don Lescohier. 1925: Can Business Prevent Unemployment? New York: A.A. Knopf.

Linder, Marc. 1989. “The Minimum Wage as Industrial Policy: A Forgotten Role,” Journal of Legislation, Vol. 16, No. 1, 151-71.

Lucas, Robert, and Leonard Rapping. 1969. "Real Wages, Employment, and Inflation,” Journal of Political Economy, Vol. 77 (June), pp. 721-54.

Madsen, Jakob. 2004. "Price and Wage Stickiness During the Great Depression," European Review of Economic History, Vol. 8, No. 3, pp. 263-95.

McCracken, Harlan. 1933. Value theory and Business Cycles. New York: Falcon Press. . 1961. Keynesian Economics in the Stream of Economic Thought. Baton Rouge, LA: Louisiana State University Press.

Meyer, Stephen. 1981. The Five Dollar Day: Labor, Management, and Social Control in the Ford Motor Company, 1908-1921. Albany, NY: State University of New York Press. Miller, Gary (1991), Managerial Dilemmas, Cambridge: Cambridge University Press. 
Milnow, Alex. 1992. “The Evolution of J.M. Keynes' Wage and Employment Theory, 19201946," History of Economics Review, Vol. 17 (Winter), pp. 47-78.

Mitchell, Daniel. 1984. "Inflation, Unemployment, and the Wagner Act: A Critical Reappraisal," Stanford Law Review, Vol. 38 (April), pp. 1065-95. . 1985. "Wage Flexibility Then and Now," Industrial Relations, Vol. 24, No. 2, pp. 266 $-79$. . 1986. "Wages and Keynes: Lessons from the Past," Eastern Economic Journal, Vol. 12, No. 3, pp. 199-208. . 1993. Keynesianism, Old Keynesianism, and New Keynesian Wage Nominalism,” Industrial Relations, Vol. 32, No. 1, pp. 1-29.

Moggridge, Donald. 1982. The Collected Writings of John Maynard Keynes, Vols. 20 and 21. London: Macmillan.

Morgan, Mary, and Malcolm Rutherford. 1998. From Interwar Pluralism to Postwar Neoclassicism. Raleigh, NC: Duke University Press.

Moriguchi, Chiaki. 2005. "Did American Welfare Capitalists Breach Their Implicit Contracts During the Great Depression? Preliminary Findings from Company-level Data," Industrial and Labor Relations Review, Vol. 59, No. 1, pp. 51-81.

Nelson, Daniel. 2000. "The AFL and the Challenge of Company Unionism.” In Bruce Kaufman and Daphne Taras, eds., Nonunion Employee Representation, pp. 61-75. Armonk, NY: M.E. Sharpe. 
Nevins, Allan. 1954. Ford: The Times, the Man, the Company. New York: Scribner's.

Neumark, David. 2009. “Delay the Minimum Wage Hike,” Wall Street Journal, (June 12), p. A15.

O'Brien, Anthony. 1989. “A Behavioral Explanation for Nominal Wage Rigidity During the Great Depression,” Quarterly Journal of Economics, Vol. 104, No.4, pp. 719-35.

Ohanian, Lee. 2009. “What—or Who - Started the Great Depression?” Journal of Economic Theory, Vol. 144, No. 6, pp. 2310-35.

Ozanne, Robert. 1968. Wages in Theory and Practice: McCormick and International Harvester, 1860-1960. Madison, WI: University of Wisconsin Press.

Parker, Randall. 2007. The Economics of the Great Depression. Northampton, MA: Edward Elgar.

Perelman, Michael. 2007. The Confiscation of American Prosperity: From Right-Wing Extremism and Economic Ideology to the Next Great Depression. New York: PalgraveMacmillan.

Pigou, Arthur. 1933. The Theory of Unemployment. London: Cass.

Prasch, Robert. 2005. "The Social Cost of Labor.” Journal of Economic Issues, Vol. 39, No. 2, pp. 1-7.

Prescott, Edward. 1999. "Some Observations on the Great Depression," Federal Reserve Bank of Minneapolis Quarterly Review, Vol. 23, No. 1, pp. 25-29.

Raymond, Daniel. 1930. "Flight from High Wages," Outlook and Independent, (July 30), pp. 498-500, 516-17.

Rees, Albert. 1970. “On Equilibrium in Labor Markets,” Journal of Political Economy, Vol. 78, No. 2, pp. 306-10. 
Riggi, Marriana. 2010. "Nominal and Real Wage Rigidities in New Keynesian Models: A Critical Survey," Journal of Economic Surveys, Vol. 24, No. 3, pp. 539-72.

Romasco, Albert. 1983. The Politics of Recovery: Roosevelt's New Deal. New York: Oxford University Press.

Romer, Christina. 1993. "The Nation in Depression," Journal of Economic Perspectives, Vol. 7, No. 2, pp. 19-39.

Rosen, Eliott. 1977. Hoover, Roosevelt, and the Brains Trust: From Depression to New Deal. New York: Columbia University Press.

Rosenof, Theodore. 1975. Dogma, Depression, and the New Deal. Port Washington, NY: Kennikat Press. 1983. Patterns of Political Economy in America: The Failure to Develop a Democratic Left Synthesis, 1933-1950. New York: Garland.

Rothbard, Murray. 1972. America's Greatest Depression. Los Angeles, CA: Nash.

Rutherford, Malcolm, and C. Tyler Desroches. 2008. “The Institutionalist Reaction to Keynesian Economics," Journal of the History of Economic Thought, Vol. 30, No. 1, 29-48.

Samuelson, Paul. 1946. "Lord Keynes and The General Theory," Econometrica, Vol. 14 (July), pp. 187-200. 1948. Economics, An Introductory Analysis. New York: McGraw Hill.

Shapiro, Carl, and Joseph Stiglitz. 1984. "Equilibrium Unemployment as a Worker Discipline Device," American Economic Review, Vol. 74, No. 3, pp. 433-44. 
Sharif, Mohammed. 2000. "Inverted 'S' - The Complete Neoclassical Labor Supply Function," International Labor Review, Vol. 139, No. 4, pp. 379-408.

Shidle, Norman. 1920. "How an Effective Employment Department is Being Developed," Automotive Industries, (August 19), pp. 370-73.

Sismondi, J.C.L. 1819 (1951). Nouveaux Principes d'Economie Politique, $3^{\text {rd }}$ ed. Geneva: Jeheber.

Skidelsky, Robert. 1983. John Maynard Keynes: The Economist as Savior, 1920-37, Vol. 2, New York, Penguin. .2009. Keynes: Return of the Master. New York: Public Affairs.

Slichter, Sumner. 1928. "The Secret of High Wages," New Republic, Vol. 54, No. 695, pp. 18385.

Sobel, Robert. 1975. Herbert Hoover at the Onset of the Great Depression, 1929-1930. New York: Lippincott.

Solow, Robert. 1990. The Labor Market as a Social Institution, New York, Blackwell.

Stabile, Donald. 1993. Activist Unionism: The Institutional Economics of Solomon Barkin, Armonk, M.E. Sharpe. . 2008. The Living Wage: Lessons from the History of Economic Thought. Northampton, MA: Edward Elgar.

Stiglitz, Joseph. 2010. Freefall: America, Free Markets and the Sinking of the World Economy. New York: Norton. 
Temin, Peter. 2007. "Peter Temin.” In The Economics of the Great Depression, Randall Parker, ed., pp. 29-51. Northampton, MA: Edward Elgar.

Tipper, Harry. 1922. "Fundamental of Labor Question Ignored," Automotive Industries, (April 20), pp. 878-79.

Tobin, James. 1975. "Keynesian Models of Recession and Depression," American Economic Revi ew, Vol. 65, No. 2, pp. 195-02.

Tymoigne, Eric. 2003. “Keynes and Commons on Money,” Journal of Economic Issues, Vol. 37, No. 3, pp. 527-45.

Vittoz, Stanley. 1987. New Deal Labor Policy and the American Industrial Economy. Chapel Hill, NC: University of North Carolina Press.

Walton, Gary, and Hugh Rockoff. 2005. History of the American Economy, $10^{\text {th }}$ ed. Mason, OH: Southwestern-Thompson.

Walton, Richard. 1986. "From Control to Commitment in the Workplace," Harvard Business Review, Vol. 63, No. 2, pp. 76-84.

Wandersee, Winifred. 1993. "I'd Rather Pass a Law Than Organize a Union: Frances Perkins and the Reformist Approach to Organized Labor." Labor History, Vol. 34, No. 1, pp. 5-32.

Webb, Sidney. 1912. "The Economic Theory of a Legal Minimum Wage," Journal of Political Economy, Vol. 20, No. 10, pp. 973-98.

Whalen, Charles. 1993. "Saving Capitalism By Making It Good: The Monetary Economics of John. R. Commons," Journal of Economic Issues, Vol. 27, No. 4, pp. 1155-79. 
. 2008a. "Toward 'Wisely Managed' Capitalism: Post-Keynesian Institutionalism and the Creative State," Forum for Social Economics, Vol. 37, No. 1, pp. 43-60.

. 2008b. "John R, Commons and John Maynard Keynes on Economic History and

Policy: The 1920s and Today," Journal of Economic Issues, Vol. 42, No. 1, pp. 225-42.

. 2010. Rethinking Economics: Analyzing Instability and Securing Prosperity after the

Great Recession. Northhampton, MA: Edward Elgar (forthcoming). 